Rapid Reviews COVID-19

\title{
Review 2: "Interleukin-6 Receptor Antagonists in Critically III Patients with Covid-19 - Preliminary report"
}

\section{Mike Samsonov ${ }^{1}$}

${ }^{1}$ Associated Professor, Sechenov Moscow Medical Academy: Pervyj Moskovskij gosudarstvennyj medicinskij universitet imeni I M Secenova, Pharmacology, Russian Federation

Published on: Mar 01, 2021

License: Creative Commons Attribution 4.0 International License (CC-BY 4.0). 


\section{$\underline{\text { RR:C19 Evidence Scale rating by reviewer: }}$}

- Strong. The main study claims are very well-justified by the data and analytic methods used. There is little room for doubt that the study produced has very similar results and conclusions as compared with the hypothetical ideal study. The study's main claims should be considered conclusive and actionable without reservation.

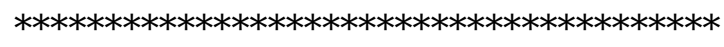

\section{Review:}

A very interesting part of the global evaluation of different treatment cohorts supporting the role of IL6 inhibitors in the reduction of mortality in ICU and duration of hospitalization.

Based on treatment arm allocation, the sarilumab cohort is relatively small (48 pts) compared to tocilizumab and the control, which may lead to a misbalance and some wrong assumptions regarding sarilumab.

However, there is a need to provide more details and information, such as:

1. A list of the standard of treatment medicines in all research cohorts. It's not clear that all groups were equally balanced especially for remdesivir.

2. Dexamethasone dosage and duration of treatment in each cohort is not clear and may have an impact on the outcome.

3. The disease duration and clinical symptoms like high temperature ( $>38 \mathrm{C})$ may be important to compare between groups. 